Ann. Génét. Sél. anim., I980, 12 (3), 28I-290.

\title{
Inheritance of body weight and breast length at 8 weeks of age in meat type strains of chickens
}

\author{
H. AYOUB, M. KHIRELDIN(*) and S. SHALASH(*) \\ Faculty of agriculture \\ Ain shams university, Cairo, Egypt
}

\begin{abstract}
Summary
Two pure strains of meat type chickens were used, White Plymouth Rock and Light Sussex. They were involved in a cross breeding programme. Heterotic effect on body weight was present and confirmed the theory of homogenetic heterosis. Performances and heritabilities of body weight at 8 weeks of age and breast length at the same age were estimated. Results showed a high magnitude of heritabilities for these two characters.

A high positive phenotypic and genetic correlation between the two characters gives an expected response of indirect selection and suggest an advantage of establishing a selection index including breast length to improve body weight.
\end{abstract}

\section{Introduction}

The present investigation used both, White Plymouth Rock and Light Sussex breeds in a crossbreeding programme. The aim of this study was to report estimates of heritabilities of body weight and breast length at 8 weeeks of age in the two strains and their reciprocal crosses. Phenotypic and Genetic correlations between the two previous characters were reported. Many reported estimates of such parameters were available in the literature but relatively few of the reported estimates have been based on closed flock populations and crosses. The two used strains in this experiment were imported since about twenty five years ago, and kept closed in the experimental farm belonging to the Ministry of Agriculture, U.A.R.

Estimates of such genetic parameters based on random and control strains were reported by MERRITr (I966). Estimates based on unselected populations were reported by KING (I96I) and estimates based on selected population have been more numerous and summerized by StEGEL (I962).

(*) Ministry of Agriculture, Egypt. 
Estimates of heritability of body weight at 8 weeks of age were summarized by KINNEY (I969) and were of high magnitude.

Heritability estimates of breast length were reported by many investigators, GODFREY \& GOODMAN (I956) found estimates of heritabilities of breast length at 9 weeks of age using the various components methods as 0.4 . The same authers obtained phenotypic and genetic correlations between breast length and body weight, estimates were 0.3 and 0.5 respectively.

Cock et al. (I956) found heritabilities of body weight and breast length at ro weeks of age, average about 0.50 and 0.30 respectively. They also reported the phenotypic correlation between the two characters as 0.29 .

BRUNSON et al. (I956) estimated the mean phenotypic correlation between ro week body weight and breast angle to be 0.19 for males and o.I3 for females.

Finally these estimates, in addition to characterizing the population itself, can be useful in selecting either for one character or to be involved in selection index programme to obtain maximum progress in both characters.

\section{Material and methods}

This experiment was carried out during I 975 and I 976 at E1 Kanater-Khairia, Research Station belonging to the Agricultural Research Centre, Ministry of Agriculture, U.A.R.

Two breeds were used in this experiment, namely, White Plymouth Rock (PP) and Light Sussex (SS). The two pure breeds and their reciprocal crosses were obtained.

Sixteen pedigree pens were available, eight of them were headed by sires from $\mathrm{PP}$ and others were headed by sires from SS strain. In respect to females, equal number of dams from each strain were distributed randomly into each pedigree pen.

\section{TABLE I}

Number of sires, dams and offspring in the 2 years Nombre de pères, de mères et de descendants dans les 2 années

\begin{tabular}{|c|c|c|c|c|c|c|c|c|c|}
\hline \multirow{2}{*}{ Year } & \multirow{2}{*}{ Strain } & \multicolumn{2}{|c|}{ PP } & \multicolumn{2}{|c|}{ SS } & \multicolumn{2}{|c|}{ PS } & \multicolumn{2}{|c|}{ SP } \\
\hline & & 우 & $\widehat{\sigma}$ & 우 & $\hat{0}$ & q & o & 우 & $\hat{\sigma}$ \\
\hline I975 & $\left\{\begin{array}{lll}\text { Sires } & . & . \\
\text { Dams } & . & . \\
\text { Offspring } & . & .\end{array}\right.$ & $\begin{array}{r}8 \\
36 \\
234\end{array}$ & $\begin{array}{r}8 \\
33 \\
192\end{array}$ & $\begin{array}{r}8 \\
38 \\
213\end{array}$ & $\begin{array}{r}8 \\
37 \\
148\end{array}$ & $\begin{array}{r}8 \\
42 \\
250\end{array}$ & $\begin{array}{r}8 \\
42 \\
240\end{array}$ & $\begin{array}{r}8 \\
29 \\
209\end{array}$ & $\begin{array}{r}8 \\
31 \\
168\end{array}$ \\
\hline 1976 & $\left\{\begin{array}{lll}\text { Sires } & . & . \\
\text { Dams } & . & . \\
\text { Offspring } & . & .\end{array}\right.$ & $\begin{array}{r}8 \\
27 \\
148\end{array}$ & $\begin{array}{r}8 \\
29 \\
140\end{array}$ & $\begin{array}{r}8 \\
33 \\
137\end{array}$ & $\begin{array}{r}8 \\
33 \\
130\end{array}$ & $\begin{array}{r}8 \\
37 \\
187\end{array}$ & $\begin{array}{r}8 \\
37 \\
193\end{array}$ & $\begin{array}{r}8 \\
28 \\
165\end{array}$ & $\begin{array}{r}8 \\
28 \\
150\end{array}$ \\
\hline
\end{tabular}


Body weight and length of breast were recorded at 8 weeks of age. Table I summarizes the number of sires, dams and offsprings which were used in this experiment.

Three hatches were available for each year during March. Hatched chickens were in floor pens and were fed ad libitum with diet contains 20 p. Ioo crude protein and $2700 \mathrm{kcal} . / \mathrm{kg}$.

\section{Methods of analysis}

Phenotypic correlations and analysis of variance were carried out according to SNEDECOR \& CoCHRAN (I967). Heritability lestimates and genetic correlations were obtained by various components method according to KEMPTHORNE (1957).

\section{Results and discussion}

\section{I. - Body weight at 8 weeks of age}

Mean body weight at 8 weeks of age for the two pure breeds (PP and SS) and their reciprocal crosses are presented in table 2 .

Regarding the first year, females of SP crosses were the heaviest, followed by PS crosses, PP strain and finally SS strain showed the lowest body weight.

\section{TABLE 2}

Body weight: mean, standara deviation and cafficicnt of variation at 8 weeks of age for each sex

Poids corporels: moyenne, écart-type et cafficient de variation $\grave{a} 8$ semaines d'âge pour chaque sexe

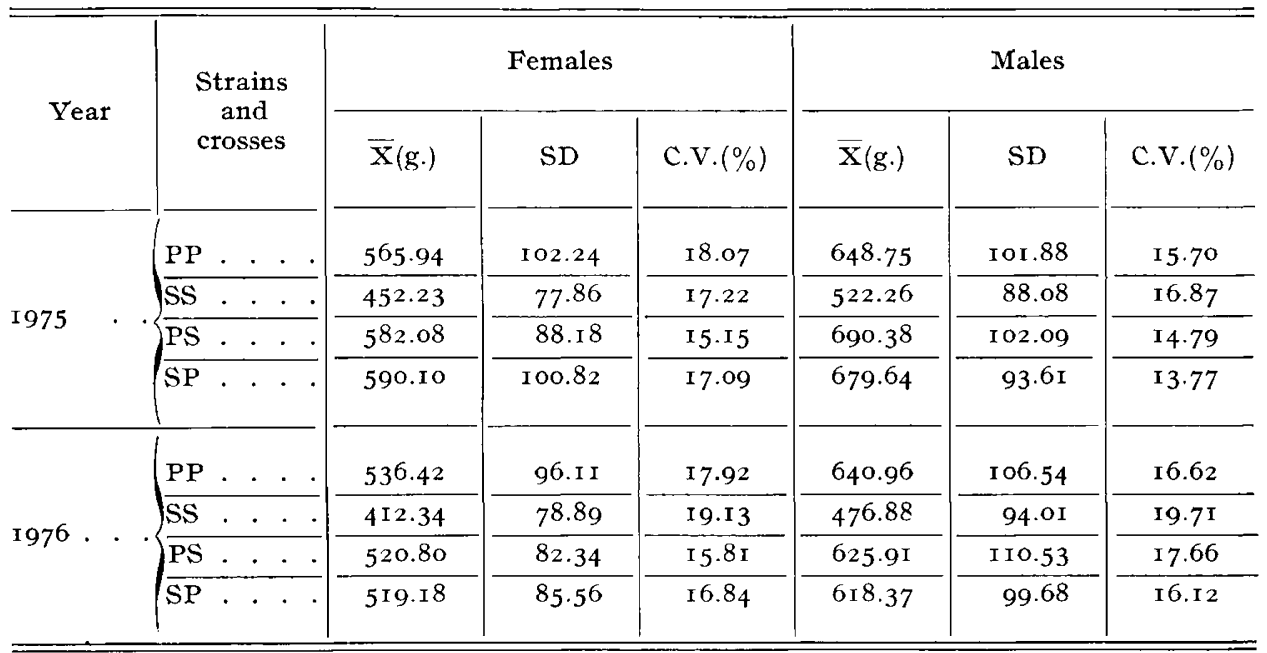


In the second season PP strain was the heaviest followed by PS, SP and finally SS. The intermediate parental body weight in the first season was 5Io $g$ and the mean body weights of crosses were 582 and $590 \mathrm{~g}$. for SP and PS respectively. In the second year the intermediate parental body weight was 474 grams and the mean body weights of the crosses were $52 \mathrm{I}$ and $5 \mathrm{Ig} \mathrm{g}$. for PS and SP respectively.

As for males in the first year PS crosses were the heaviest followed by SP, PP and SS strain. In the second season PP strain was the heaviest followed by PS and SP crosses and latest SS strain. These results showed the same trend as for females in both years indicating that the two reciprocal crosses execeded the mean body weights of the two pure breeds in the first year and the mean parental body weight in the second year.

Thus, the role of dominance and over dominance effect is important in the inheritance of body weight at 8 weeks of age in the studied genetic groups.

Table 2 shows a tendancy for females to have a greater cœfficient of variation than males. Crosses generally showed a lower cœefficient of variation than the pure breeds which agrees with available references, stating a greater sensitivity of pure breeds to uncontrolled environmental conditions than for crosses. However the variances did not show great differences according to sex and genotypes.

\section{2. - Heterotic effect for each sex}

The differences between sexes were in general greater in the crosses than the two pure breeds, being $82.8,70,0$, ro8.3 and $89.5 \mathrm{~g}$. for PP, SS, PS, and SP strain in the first year respectively, while they were in the same order 104.5, 64.5 , I05.I and 99.3 grams in the second year. Table 3 shows the herotic percentage of the two crosses over the parental body weight. In all crosses males gained more from crosses than females.

It could be observed that heterotic effects were greater in I975 than 1976 . Table 4 shows that there was a highly significant difference between years and systems of mating. The year effect may be due to uncontrolled enviromental factors such as temperature, humidity, etc... Interaction between system of mating and year was significant for both sexes. The results suggest different response to these uncontrolled factors according to genetic makenup as show- in

TABLE 3

Body weight: percentage of heterotic effect for cach sex

Poids corporel: pourcentage de l'effet hétérotique pour chaque sexe

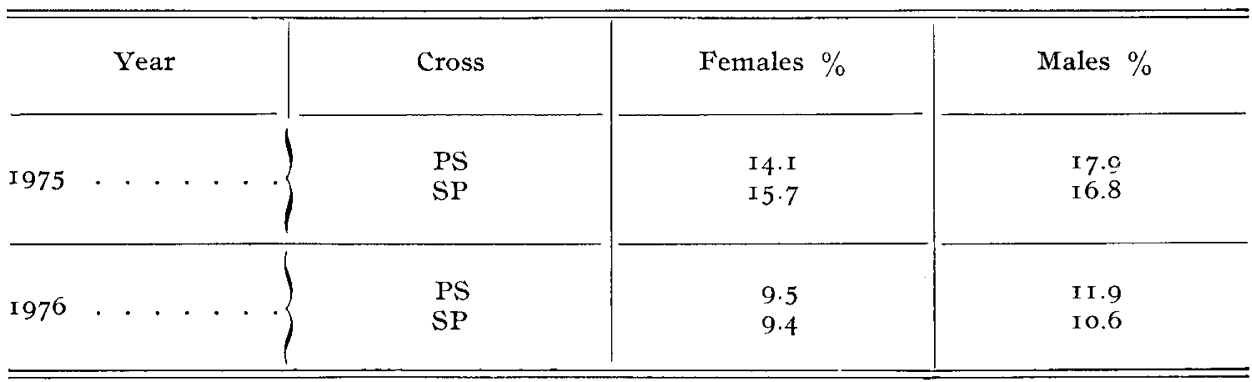


TABI,E 4

Analysis of variance for body weight according to year and system of mating

for each sex separately at 8 weeks of age

Analyse de variance pour le poids corporel à 8 semaines d'âge selon l'année et le type génétique pour chaque sexe séparément

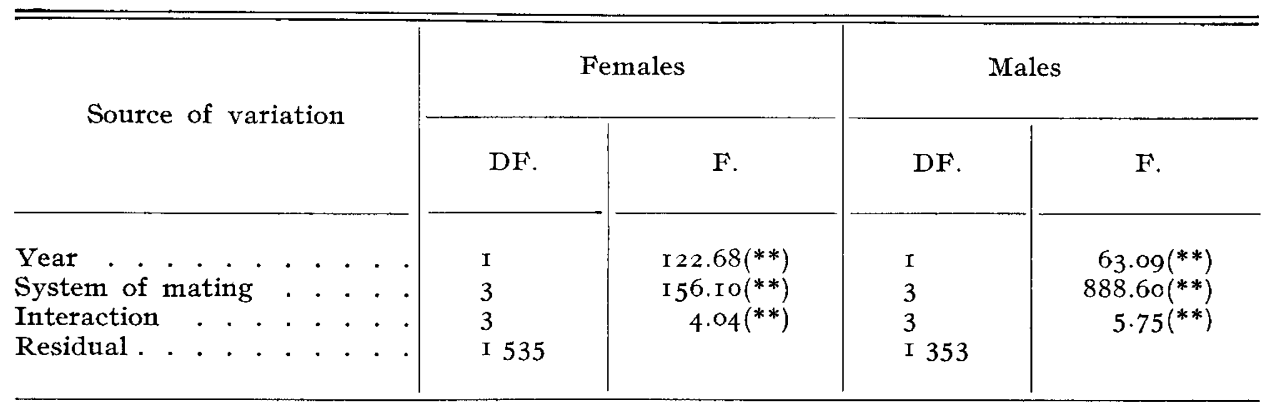

(**) Significant at I p. Ioo level.

TABLE 5

Analysis of variance for body weight according to sex and system of mating at 8 weeks of age Analyse de variance pouv le poids corporel à 8 semaines d'âge selon le sexe et le type génétique

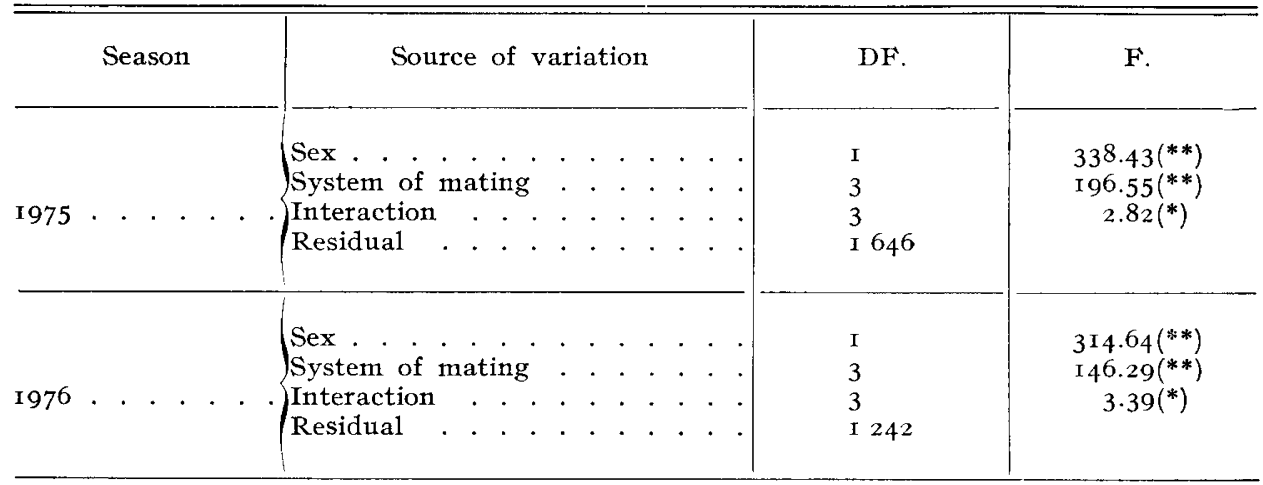

(**) Significant at I p, roo level.

(*) Significant at 5 p. roo level.

table 2. It may be also stated that the heterotic effect is expected to be greater in better conditions.

These results were also tested by analysis of variance with two controlled factors, sex and system of mating. This analysis of variances was listed in table 5. Results showed a significant effect of sex and system of mating on body weight at 8 weeks of age at I p. Ioo level, while the variances of interaction were significant at $5 \mathrm{p}$. roo level. 
These results may confirm the term of homoganetic heterosis suggested by STONAKER (I963). It should be mentioned that the two strains were kept closed since more than 25 years.

\section{3. -- Breast length at 8 weeks of age}

Table 6 shows the mean, standard deviation and coefficient of variation of breast length for both sexes in the two years at 8 weeks of age.

Generally the Ligth Sussex females showed the shortest breast length while

TABLE 6

Breast length: mean $(\mathrm{mm})$, standard deviation and coefficient

of variation for each sex at 8 weeks of age

Longueur du bréchet: moyenne $(\mathrm{mm})$, écart-type et cofficient de variation pour chaque sexe $\dot{a} 8$ semaines d'âge

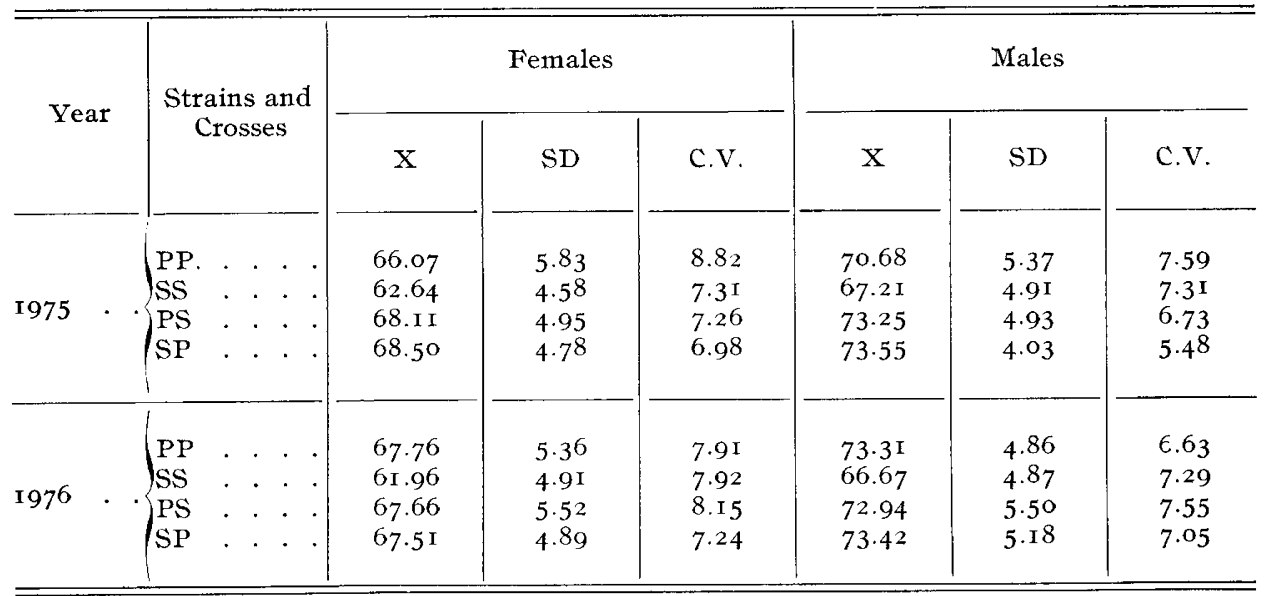

the pure White Plymouth Rock and the two crosses showed approximately the same length. In respect to males, they showed a greater breast length than females. The Light Sussex was the shorter all over the experiment while the two crosses showed superior length than the pure Plymouth in the first year, and nearly the same, in the second year. These results in general may confirm the importance of dominance and overdominance effect on the inheritance of this character. The cœfficient of variation results did not show a considerable difference among the studied genetic groups.

\section{4. - Heritability estimates of body weight at 8 weeks of age}

Table 7 presents the estimates of heritability as obtained by variance components. Estimates when obtained by dams components of variance were higher than those based on sire components of variance, in 25 cases out of 30 . The 
relative importances of sire components of variance were slightly greater for males than females. These findings may suggest that sex linked genetic variance was not of much importance in the inheritance of body weight in the studied groups. MERRITT (I966) stated that in birds, the sire components would contain one quarter and one half of the additive sex linked genetic variance, while the dam component would contain one half and none when the analyses are based on males and females respectively. Moreover, the dominance variance due to sex linked genes would not exist for females. Estimates of heritabilities based on pooled data were for females $0.30,0.53$ and 0.42 when obtained by paternal, maternal and average component respectively. They were in the same order $0.40,0.70$

TABIE 7

Heritability estimates for body weight at 8 weeks of age

Estimation d'héritabilité pour le poids corporel à 8 semaines d'âge

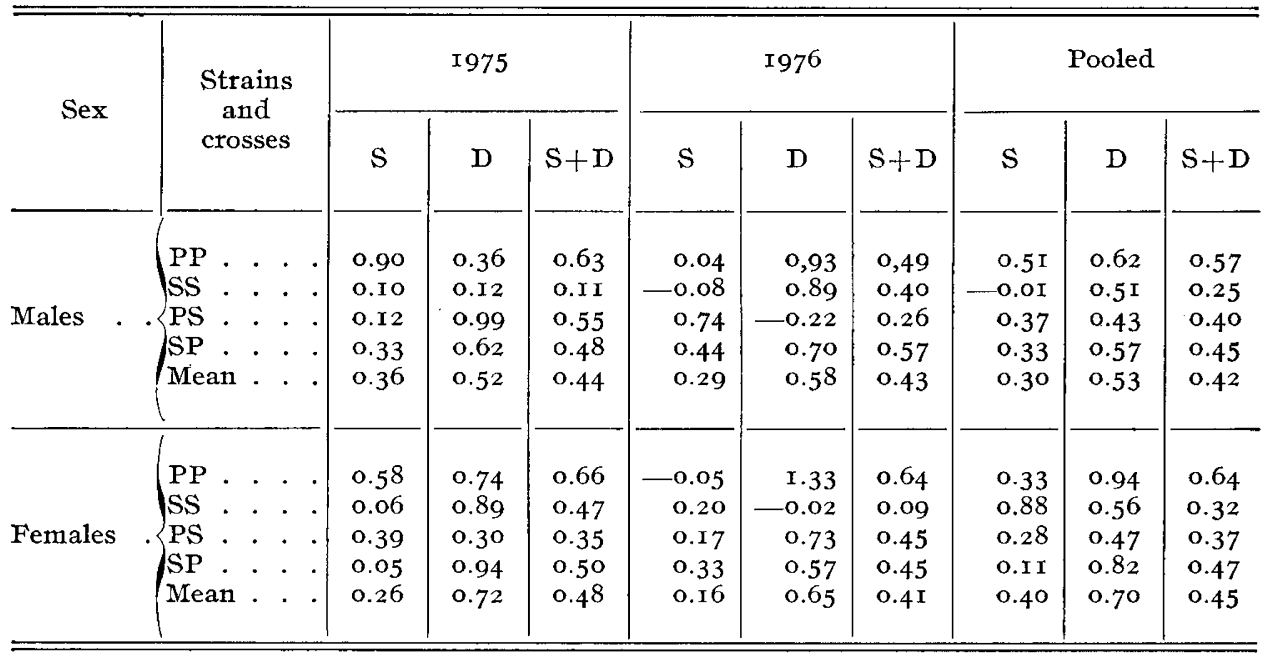

and 0.45 for females. These values were within the estimates listed in the literatures e.g. KINNEY (I969). Heritability estimates did not show different magnitude as obtained for pure strains or crosses.

\section{5. - Heritability estimates of breast length at 8 weeks of age}

Table 8 presents the estimates of heritabilities of breast length, based on variance components. It could be summarized as follows, for males, the pooled estimates were $0.38,0.47$ and 0.43 as obtained by sire, dam, component and their average respectively.

For females pooled estimates were in the same order $0.28,0.50$ and 0.39 . These estimates were within the available estimates of many references. Some of these estimates were negative or higher than unit, that may be due to sampling error or scaling effect (FALCONER, I960). 


\section{TABLE 8}

Heritability estimates of breast length at 8 weeks of age Estimations d'héritabilité de la longueur de bréchet à 8 semaines d'âge

\begin{tabular}{|c|c|c|c|c|c|c|c|c|c|c|}
\hline \multirow{2}{*}{ Sex } & \multirow{2}{*}{$\begin{array}{l}\text { Strains } \\
\text { and } \\
\text { crosses }\end{array}$} & \multicolumn{3}{|c|}{ I975 } & \multicolumn{3}{|c|}{1976} & \multicolumn{3}{|c|}{ Pooled } \\
\hline & & s & D & $\mathrm{S}+\mathrm{D}$ & $\mathrm{S}$ & D & $\mathrm{S}+\mathrm{D}$ & $S$ & $\mathrm{D}$ & $\mathrm{S}+\mathrm{D}$ \\
\hline Males & 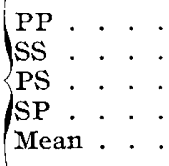 & $\begin{array}{l}\text { I. } 22 \\
0.21 \\
0.37 \\
0.09 \\
0.47\end{array}$ & $\begin{array}{l}0.17 \\
0.18 \\
0.58 \\
0.1 \mathbf{1} \\
0.26\end{array}$ & $\begin{array}{l}0.69 \\
0.19 \\
0.47 \\
0.10 \\
0.36\end{array}$ & $\begin{array}{r}0.20 \\
-0.22 \\
0.70 \\
0.39 \\
0.27\end{array}$ & $\begin{array}{r}0.74 \\
\text { x.14 } \\
-0.04 \\
0.93 \\
0.69\end{array}$ & $\begin{array}{l}0.47 \\
0.46 \\
0.35 \\
0.66 \\
0.48\end{array}$ & $\begin{array}{l}0.78 \\
0.00 \\
0.49 \\
0.24 \\
0.38\end{array}$ & $\begin{array}{l}0.38 \\
0.62 \\
0.29 \\
0.60 \\
0.47\end{array}$ & $\begin{array}{l}0.58 \\
0.31 \\
0.39 \\
0.42 \\
0.43\end{array}$ \\
\hline Females & 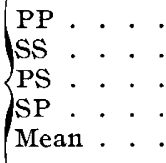 & $\begin{array}{r}0.64 \\
-0.10 \\
0.44 \\
0.11 \\
0.27\end{array}$ & $\begin{array}{l}0.76 \\
0.75 \\
0.40 \\
0.36 \\
0.57\end{array}$ & $\begin{array}{l}0.70 \\
0.33 \\
0.42 \\
0.24 \\
0.42\end{array}$ & $\begin{array}{l}0.11 \\
0.29 \\
0.33 \\
0.60 \\
0.33\end{array}$ & $\begin{array}{r}\mathrm{I} .34 \\
-0.50 \\
0.47 \\
0.34 \\
0.41\end{array}$ & $\begin{array}{l}0.73 \\
0.1 \text { I } \\
0.40 \\
0.47 \\
0.37\end{array}$ & $\begin{array}{l}0.42 \\
0.04 \\
0.36 \\
0.29 \\
0.28\end{array}$ & $\begin{array}{l}0.96 \\
0.26 \\
0.43 \\
0.36 \\
0.50\end{array}$ & $\begin{array}{l}0.69 \\
0.15 \\
0.40 \\
0.33 \\
0.39\end{array}$ \\
\hline
\end{tabular}

\section{6. - Phenotypic correlation between body weight and breast length}

Table 9 presents the phenotypic correlation between the two characters. A1l estimates ranged from 0.36 to 0.92 . These results suggest a close positive correlation between the two characters in both sexes.

\section{TABLE 9}

Phenotypic correlation between body weight

and breast length for males and females at 8 weeks of age

Corrélations phénotypiques entro le poids corporel à 8 semaines d'age et la longueur du bréchet pour les mâles et les femelles

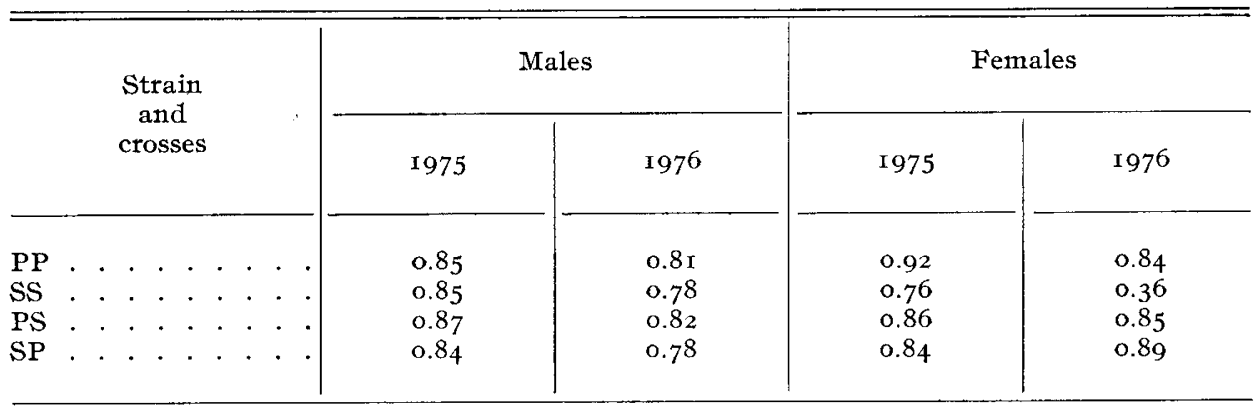

All estimates eere significant at I p. Ioo level. 


\section{7. - Genetic correlation}

Table Io shows that in general there was a bigh genetic correlations between the two characters. These results indicated that selection programme carried out for body weight will lead to a considerable increase in breast length, and improve conformation.

\section{TABLE IO}

Genetic correlation between body weight and breast length at 8 weeks of age

Corrélation génétique entre le poids corporel et la longueur du bréchet à 8 semaines d'âge

\begin{tabular}{|c|c|c|c|c|c|c|c|c|c|c|}
\hline \multirow{2}{*}{ Sex } & \multirow{2}{*}{$\begin{array}{l}\text { Strain } \\
\text { and } \\
\text { crosses }\end{array}$} & \multicolumn{3}{|c|}{ I975 } & \multicolumn{3}{|c|}{1976} & \multicolumn{3}{|c|}{ Pooled } \\
\hline & & $\mathrm{S}$ & $\mathrm{D}$ & $\mathrm{S}+\mathrm{D}$ & $S$ & $\mathrm{D}$ & $\mathrm{S}+\mathrm{D}$ & $\mathrm{S}$ & D & $\mathrm{S}+\mathrm{D}$ \\
\hline Males & $\left\{\begin{array}{l}\mathrm{PP} \\
\mathrm{SS} \\
\mathrm{PS} \\
\mathrm{SP}\end{array}\right.$ & $\begin{array}{l}0.96 \\
0.80 \\
\text { I.1 } 7 \\
0.80\end{array}$ & $\begin{array}{r}0.84 \\
-0.56 \\
0.48 \\
\text { I. I } 2\end{array}$ & $\begin{array}{l}0.91 \\
0.12 \\
0.59 \\
0.98\end{array}$ & $\begin{array}{c}0.59 \\
- \\
0.91 \\
1.01\end{array}$ & $\begin{array}{l}\mathbf{1 . 0 4} \\
0.99 \\
-.88\end{array}$ & $\begin{array}{l}0.96 \\
\text { I. } 01 \\
0.59 \\
0.92\end{array}$ & $\begin{array}{l}0.96 \\
- \\
0.97 \\
0.90\end{array}$ & $\begin{array}{l}0.97 \\
0.79 \\
0.44 \\
0.88\end{array}$ & $\begin{array}{l}0.94 \\
0.80 \\
0.72 \\
0.88\end{array}$ \\
\hline Females & $\left\{\begin{array}{l}\mathrm{PP} \\
\mathrm{SS} \\
\mathrm{PS} \\
\mathrm{SP}\end{array}\right.$ & $\begin{array}{l}\text { I.I } 2 \\
- \\
0.94 \\
0.30\end{array}$ & $\begin{array}{l}0.57 \\
0.87 \\
0.86 \\
0.96\end{array}$ & $\begin{array}{l}0.8 \mathrm{I} \\
0.93 \\
0.90 \\
0.80\end{array}$ & $\begin{array}{l}- \\
- \\
0.74 \\
1.09\end{array}$ & $\begin{array}{l}\text { I.OI } \\
-\overline{0.94} \\
0.88\end{array}$ & $\begin{array}{l}1.00 \\
\overline{0.85} \\
0.95\end{array}$ & $\begin{array}{l}\overline{-} \\
\overline{0.88} \\
0.97\end{array}$ & $\begin{array}{l}0.77 \\
- \\
0.89 \\
0.88\end{array}$ & $\begin{array}{l}0.9 \mathrm{I} \\
0.88 \\
0.84\end{array}$ \\
\hline
\end{tabular}

- Un estimated due to the negative values of sires or dams components of variance either for body weight or breast length.

On the other hand, breast length may be of some advantage when included in selection indexes to improve body weight regarding its rather high heritability and positive genetic and phenotypic correlation with body weight.

Received for publication in november $\mathbf{9} 980$.

\section{Résumé}

Hérédité du poids corporel et de la longueur du bréchet à 8 semaines d'âge dans des souches de poulets de chair

Deux souches pures de poulets de chair, Plymouth Rock blanche et Sussex herminée, ont été utilisées dans un programme de croisements. Un effet d'hétérosis sur le poids corporel était présent et apportait une confirmation à la théorie de l'hétérosis homogamétique. Les moyennes écart-type et héritabilité du poids corporel et de la longueur du bréchet à 8 semaines d'âge ont été estimées. Les résultats montrent des héritabilités relativement élevées pour ces đeux caractères. 
Une corrélation phénotypique et génétique positive élevée entre les deux variables permet d'obtenir une prévision de réponse à une sélection indirecte et suggère qu'un index de sélection incluant la longueur du bréchet serait avantageux pour améliorer le poids corporel.

\section{References}

Brunson C. C., Godfrex F., Goodman B. L., 1956. Types of gene action in the inheritance of ten week body weight and breast angle in broilers. Poult. Sci., 35, 524-532.

Cock R. E., Clark T. B., Dumbar R. S., Cunningham C. J., I956. The correlation between broiler qualities, the heritability estimates of these qualities and the use of selection indexes in chickens. Poult. Sci., 35, II37.

FALCONER D. S., I960. Introduction to quantitative genetics. Oliver and Boyd, London.

GODFREY F. F., Goodman B. L., I956. Genetic variation and covariation in broiler body weight and breast width. Poult. Sci., 35, 47.

KEMPTHORE O., I957. An introduction to genetic statistics. John Wiley and Sons, New-York.

KING S. C., I96I. Inheritance of economic traits in the regional Cornell Control population. Poult. Sci., 40, 975-986.

KINNEY T. B., I969. A summary of reported estimates of heritabilities, of genetic and phenotypic correlations for traits of chickens. A gricultural Handbook 363. Agric. Res. Service, USDA.

MERRITT E. S., 1966. Estimates by sex of genetic parameters for body weight and skeletal dimensions in a random bred strain of meat type fowl. Poult. Sci., 45, II8-I25.

SIEGEL P. B., I962. Selection for body weight at 8 weeks of age. Poult. Sci., 41, 954-962.

SNedicor G. W., Cochran W. G., 1967. Statistical methods. Sixth edition, Ames, Iowa, USA.

STONAKER H. H. 1963. A genetic hypothesis for sex-mating system interaction in growth of cattle and poultry. J. Anim. Sci., 22, 320-325. 